\title{
STANDAR HUJAN EKSTRIM DI RIAU MENGGUNAKAN METODE REGRESI KUANTIL
}

\author{
Aristya Ardhitama ${ }^{1}$, Yessy Christy Ulina ${ }^{2}$
}

\begin{abstract}
Intisari
Salah satu akibat dari adanya fenomena penamasan global dan perubahan iklim adalah meningkatnya kasus kejadian cuaca ekstrim dan iklim ekstrim yang terjadi di hampir sebagian besar wilayah Indonesia khususnya di wilayah Riau. Hingga kini belum ada batasan yang jelas atau standar tentang suatu kondisi cuaca dan iklim yang dapat dikategorikan ekstrim. Dari hasil perhitungan curah hujan ekstrim di Riau dengan 2 daerah sampel pos hujan yaitu data Stamet Pekanbaru dan Stamet Japura Rengat, menggunakan metode regresi kuantil, untuk Kota Pekanbaru nilai ekstrim tertinggi pada bulan November $518 \mathrm{~mm}$ dan nilai ekstrim terendah $28 \mathrm{~mm}$ pada bulan Juli. Sedangkan untuk di daerah Rengat nilai batas atas untuk curah hujannya pada bulan Desember $431.4 \mathrm{~mm}$ dan untuk batas bawah $14.3 \mathrm{~mm}$. Nilai ekstrim untuk curah hujan bermanfaat untuk peringatan dini banjir dan kekeringan.
\end{abstract}

\begin{abstract}
One of the global warming and climate change effects is increased number of extreme weather events and extreme climate events that occurred in most of Indonesia region, Riau in particular. Yet, there are no distinct border or any standard definition for those events to be categorized as extreme events. Extreme rainfall events have been calculated using 2 weather station data as sample in this paper, those are Pekanbaru and Japura Rengat station, with quantile regression method. For Pekanbaru station, the highest rainfall event is in November with $518 \mathrm{~mm}$ monthly rainfall, and the lowest rainfall event is in July with $28 \mathrm{~mm}$ monthly rainfall. For Japura Rengat station the highest rainfall event is in December with $431.4 \mathrm{~mm}$ monthly rainfall, and the lowest rainfall event is 14.3 $\mathrm{mm}$ monthly rainfall. Extreme rainfall can be used for flood and drought early warning.
\end{abstract}

Kata Kunci : Perubahan Iklim, Iklim Ekstrim, Hujan Ekstrim.

\section{PENDAHULUAN}

Pemanasan global dan perubahan iklim bukan lagi menjadi hanya isu atau masalah di masa depan melainkan sudah menjadi masalah yang kita hadapi sekarang. Hasil penelusuran database bencana internasional (International Disasster Database), jumlah bencana alam yang masuk ke dalam kategori bencana global adalah sebanyak 345 bencana ${ }^{[2]}$. Hasil penemuan ini sejalan dengan kajian panel antar pemerintah tentang perubahan iklim $^{[4]}$ bahwa pemanasan global akan meningkatkan frekuensi dan intensitas kejadian iklim ekstrim. Para peneliti dari berbagai belahan dunia mulai resah dengan peningkatan suhu bumi saat ini dan kekhawatiran akan dampaknya yang luar biasa. Bahkan mereka memberi perhatian khusus akan bahaya yang ditimbulkan oleh pemanasan global dan perubahan iklim saat ini terhadap umat manusia yang menjadi ancaman serius terhadap kelangsungan makhuk hidup khususnya manusia yang hidup di bumi ini ${ }^{[6]}$.

Salah satu akibat dari adanya fenomena penamasan global dan perubahan iklim adalah meningkatnya kasus kejadian cuaca ekstrim dan iklim ekstrim yang terjadi di hampir sebagian besar wilayah Indonesia khususnya di wilayah Riau. Kejadian cuaca dan iklim ekstrim terjadi merupakan akibat dari kenaikan suhu global yang terjadi sehingga mengakibatkan pola perubahan cuaca dan iklim di seluruh dunia.

Kondisi iklim ekstrim mempengaruhi adaptasi dan mitigasi dari manusia yang mendiami suatu tempat. Kenaikan suhu yang tinggi, kasus kejadian curah hujan lebat, dan angin puting beliung sering kali menjadi bencana dan menimbulkan korban jiwa. Kenaikan suhu yang tinggi berdampak pada gaya hidup manusia, meningkatkan penggunaan AC (Air Conditioner), padahal penggunaan AC berdampak pada banyaknya gas CFC (Cloro Floro Carbon) yang naik ke atmosfer, dan memperparah efek pemanasan global. Di samping itu, kenaikan suhu udara permukaan mendukung timbulnya berbagai penyakit terhadap manusia.

Hingga kini belum ada batasan yang jelas atau standar tentang suatu kondisi cuaca dan iklim yang dapat dikategorikan ekstrim. Dalam penelitian ini, penulis mencoba menganalisis kasus kejadian cuaca dan iklim yang terjadi di Provinsi Riau dan membuat theshold (batasan) 
dari unsur iklim yang diamati seperti curah hujan dan suhu minimum, sehingga masyarakat tahu batasan yang pasti mengenai fenomena yang dapat dikantegorikan sebagai ekstrim atau tidak.

\section{TINJAUAN TEORI}

\subsection{Pengertian dasar tentang Cuaca dan iklim}

Ada beberapa pengertian yang berkaitan dengan cuaca; menurut Trewartha ${ }^{[12]}$, cuaca adalah keadaan variabel atmosfer secara keseluruhan disuatu tempat dalam selang waktu yang pendek. Sedangkan menurut Gibbs ${ }^{[3]}$, cuaca adalah keadaan atmosfer yang dinyatakan dengan nilai berbagai parameter, antara lain suhu, tekanan, angin, kelembaban, dan berbagai fenomena hujan, disuatu tempat atau wilayah selama kurun waktu yang pendek.

Selain faktor cuaca ada hal lain yang berkaitan dengan cuaca yang disebut dengan iklim. Iklim memiliki pengertian yaitu konsep abstrak yang menyatakan kebiasaan cuaca dan unsur-unsur atmosfer disuatu daerah selama kurun waktu yang panjang ${ }^{[12]}$. Sedang menurut Gibbs $^{[3]}$, iklim adalah peluang ststistik berbagai keadaan atmosfer, antara lain suhu, tekanan, angin, kelembaban, yang terjadi pada suatu daerah selama kurun waktu yang panjang.

Dari beberapa definisi tadi dapat disimpulkan bahwa cuaca adalah keadaan fisik atmosfer pada suatu saat (waktu tertentu) di suatu tempat, yang dalam waktu singkat (pendek) berubah keadaannya, seperti panasnya, kelembabannya, atau gerak udaranya sedang iklim adalah peluang statistik keadaan cuaca ratarata atau keadaan cuaca jangka panjang pada suatu daerah, meliputi kurun waktu beberapa bulan atau beberapa tahun.

\subsection{Peyebab terjadinya Pemanasan Global.}

Pemanasan global adalah kejadian meningkatnya temperatur rata-rata atmosfer, daratan dan laut. Planet bumi telah mengalami proses menghangat dan juga mendingin dalam proses pembentukannya mulai 5 milyar tahun yang lalu. Pada saat ini bumi mengalami pemanasan yang lebih cepat, yang oleh para ilmuwan dianggap disebabkan oleh aktifitas manusia. Penyebab utama pemanasan ini adalah penggunaan bahan bakar fosil seperti batu bara, minyak bumi dan gas alam ${ }^{[5]}$.

Sejak revolusi industri tahun 1870-an, jumlah kegiatan manusia yang menggunakan bahan bakar fosil (minyak,gas dan batubara) terus meningkat. Kegiatan seperti pembangkitan tenaga listrik, kegiatan industri, penggunaan alat-alat elektronik, dan penggunaan kendaraan bermotor pada akhirnya akan melepaskan sejumlah emisi gas rumah kaca ke atmosfer. Hal ini berakibat pada meningkatnya jumlah gas rumah kaca (GRK) yang berada di atmosfer, menyebabkan meningkatnya panas matahari yang terperangkap di atmosfer.

Menurut Konvensi PBB mengenai Perubahan Iklim (United Nations Framework Convention on Climate Change -UNFCCC), ada 6 jenis gas yang digolongkan sebagai GRK, yaitu: (1) karbondioksida (CO2) $\rightarrow$ pembakaran bahan bakar fosil di sektor energi, transportasi dan industri (2) dinitro oksida (N2O) (3) metana (CH4) (4) sulfurheksaflorida (SF6) (5) perflorokarbon (PFCs) (6) hidroflorokarbon (HFCs)

Gas karbondioksida, dinitro oksida dan metana, terutama dihasilkan dari pembakaran bahan bakar fosil di sektor energi, transportasi dan industri. Gas metana juga dihasilkan dari kegiatan pertanian dan peternakan. Sementara untuk 3 jenis GRK yang terakhir, sulfurheksaflorida, perflorokarbon dan hidroflorokarbon dihasilkan dari industri pendingin dan penggunaan aerosol.

\subsection{Proses Terjadinya Efek Rumah Kaca}

Sebagian panas matahari yang merambat masuk ke bumi melintasi atmosfer diserap oleh permukaan bumi. Sebagian panas matahari yang lain akan dipantulkan kembali oleh permukaan bumi ke angkasa melalui atmosfer. Ketika dipantulkan oleh permukaan bumi, energi panas matahari ini mengalami perubahan panjang gelombang. Sebagian energi dapat lolos dari atmosfer bumi ke luar angkasa, sementara sebagian lainnya terhalang oleh adanya gas rumah kaca yang berada di atmosfer. Panas matahari tersebut terpantul kembali ke permukaan bumi, terperangkap di permukaan bumi, disebut sebagai efek rumah kaca. Peristiwa ini menjaga suhu di bumi tetap hangat. Menurut Murdiyarso ${ }^{[0]}$, gas-gas rumah kaca memiliki sifat seperti kaca di udara, yang dapat meneruskan radiasi gelombang pendek dan memantulkan radiasi gelombang panjang.

Semakin banyak jumlah gas rumah kaca yang berada di atmosfer, maka semakin banyak pula panas matahari yang terperangkap di permukaan bumi. Ketika jumlah gas rumah kaca melebihi yang dibutuhkan, bumi cenderung memanas melebihi laju normalnya. Menurut laporan Intergovermental Panel on Climate Change yang berjudul "Climate Change Impact, Adaption and Vulnerability berisi tentang ${ }^{[4]}$ :

1. Kenaikan suhu bumi rata-rata sebesar 0.7 C antar periode $1850-2005$

2. 11 dari 12 tahun terakhir (1995 - 2006) merupakan tahun-tahun dengan rata-rata

3. suhu tertinggi semenjak pertama kali dilakukan pengukuran suhu tahun 1850 
4. Telah terjadi kenaikan permukaan air laut global rata-rata sebesar $1.8 \mathrm{~mm}$ pertahun antar periode 1961 - 2003

5. Telah terjadi kekeringan yang lebih intensif pada wilayah yang lebih luas sejak tahun 1970an, terutama di daerah tropis dan sub tropis

6. IPCC memprediksikan kenaikan suhu global akan berkisar antara 1.6 - 2.4 derajat celcius pada tahun 2050 dan 2070. Berdasar prakiraan dari Canadian Climate Chane model dan United Kingdom Meteorological Office di Indonesia, akibat perubahan iklim akan mengakibatkan kenaikan suhu menjadi 1.6 - 3.0 derajat celcius pada tahun 2050 - 2070. Sedang berdasarkan prakiraan dua lembaga Amerika Serikat yakni Global Fluid Dynamic dan Goddart International Space Study, suhu Indonesia akan meningkat 2 hingga 4.2 derajat celcius.

\subsection{Perubahan Iklim}

Perubahan iklim adalah berubahnya iklim yang diakibatkan, langsung atau tidak langsung, oleh aktivitas manusia yang menyebabkan perubahan komposisi atmosfer secara global serta perubahan variabilitas iklim alamiah yang teramati pada kurun waktu yang dapat dibandingkan (Sumber : UU No. 31 Tahun 2009).

Perubahan iklim sebagai implikasi dari pemanasan global telah mengakibatkan ketidakstabilan cuaca dan iklim dibawah permukaan bumi. Perubahan suhu global menyebabkan kondisi fisis atmosfer kian tidak stabil menimbulkan kejadian terhadap anomalianomali dari parameter cuaca yang akan berlangsung lama. Dalam jangka panjang anomali - anomali parameter cuaca tersebut akan menimbulkan perubahan iklim ${ }^{[11]}$. Adapun dampak yang ditimbulkan dari perubahan iklim yang terjadi yaitu meningkatnya jumlah curah hujan yang terjadi, kenaikan suhu, dan juga seringnya kasus kejadian angin puting beliung yang semuanya berakibat bencana dan membawa dampak terhadap kehidupan manusia.

\subsection{Iklim Ekstrim}

Cuaca ekstrim adalah fenomena atau kondisi cuaca yang tidak normal, tidak lazim atau kondisi cuaca yang lain dari biasanya dalam suatu saat atau waktu tertentu. Sifat dari cuaca ekstrim adalah destruktif, biasanya merusak bahkan dapat menimbulkan korban jiwa serta harta benda. Sedangkan iklim ekstrim sendiri adalah kondisi anomali cuaca dalam jangka panjang yang tidak lazim terjadi dan biasanya membawa dampak yang merusak lingkungan.Contohnya adanya kasus curah hujan tinggi yang mempunyai siklus tertentu yang dapat menyebabkan kerusakan lingkungan, misalnya banjir. Suhu yang tinggi dari rata-ratanya menyebabkan kondisi ekstrim yang mempengaruhi kenyamanan dan menyangkut pola kemampuan adaptasi dari makhuk hidup di dalam lingkungan. Kejadian ekstrim ini merupakan salah satu dampak dari adanya peristiwa perubahan iklim. Nilai-nilai ekstrim dapat dinamakan sebagai data pencilan (outlier)

Pencilan adalah sebuah atau sejumlah pengamatan yang tidak konsisten dengan pengamatan - pengamatan lainnya dalam satu gugus data ${ }^{[1]}$. Nilai pencilan bisa terjadi karena adanya kesalahan data pengukuran atau pengamatan dan data tersebut benar karena datanya mencapai nilai maksimum atau minimum.

\subsection{Metode Regresi Kuantil}

Regresi kuantil median pertama kali diperkenalkan oleh Roger Koenker dan Gilbert Basset tahun $1978^{[6]}$. Metode regresi kuantil merupakan pengembangan dari regresi median pada berbagai nilai kuantil untuk mengetahui hubungan antara peubah respon dengan peubah prediktor pada fungsi kuantil bersyarat tertentu. Kuantil dapat dioperasikan dengan penyusunan atau pengurutan sampel pengamatan sehingga lebih mudah menentukan letaknya dan dapat mendefinisikan kuantil melalui alternatif yang sederhana sebagai masalah optimisasi.

Sama seperti metode kuadrat terkecil yang dapat mendefinisikan rata-rata sampel sebagai solusi untuk masalah me-minimumkan jumlah kuadrat error, regresi kuantil median dapat mendefinisikan median sebagai solusi untuk masalah meminimumkan jumlah absolut error. Simetri dari nilai fungsi absolut linier mengimplikasikan bahwa minimum jumlah absolut error harus sama dengan jumlah error yang positif dan negatif, sehingga menjamin bahwa terdapat jumlah pengamatan yang sama di atas dan di bawah median. Karena simetri nilai absolut menghasilkan median, diharapkan dengan meminimumkan jumlah absolut error terboboti yang tidak simetri, secara sederhana memberikan perbedaan bobot untuk error positif dan negatif akan menghasilkan kuan$\mathrm{til}^{[7]}$.

Metode regresi kuantil juga bisa digunakan untuk meminimumkan sisaan mutlak terboboti dan mengukur pengaruh peubah prediktor tidak hanya di pusat distribusi data, tetapi juga pada bagian ekor distribusi, tidak membutuhkan asumsi parametrik, dan metode ini tidak terpengaruh oleh pencilan dan dapat memberikan hasil yang stabil jika terdapat pencilan.

Regresi kuantil merupakan generalisasi konsep kuantil pada peubah tunggal ke kuantil bersyarat untuk satu atau lebih peubah penjelas. Untuk peubah acak $\mathrm{Y}$ dengan fungsi sebaran peluang 


$$
F(y)=P(Y \leq y)^{\prime}
$$

Kuantil ke-T dari $Y$ didenifisikan sebagai fungsi invers

$$
Q(T)=\inf \{y, F(y) \geq T\}
$$

dengan т $\epsilon$ (0.1), sebagai contoh median adalah $\mathrm{Q}(0.5)$

Untuk contoh acak berukuran $\mathrm{n}$ dari peubah acak $\mathrm{Y}$, yaitu $\left(y_{1}, \ldots, y_{n}\right)$ median contoh

adalah penduga yang meminumkan jumlah mutlak galat yaitu

$$
\min _{\xi \in R}=\sum_{i=1}^{n}\left|y_{i}-\xi\right|
$$

Seperti halnya median contoh, metode ini juga bisa dikembangkan untuk model regresi kuantil

$$
y=X^{\prime} \beta+\varepsilon
$$

\section{METODE}

Metode yang digunakan dalam penelitian ini adalah metode statistik yaitu metode regresi kuantil yang memberikan threshold (batasan) tentang batasan paramater iklim dengan prosedur penelitian sebagai berikut :

1. Menyiapkan series data jangka panjang dari tahun 1981 - 2010 dari dua stasiun meteorologi di Riau untuk mencari batasan ekstrim atas dan bawah dengan metode regresi kuantil.

2. Mengambil data curah hujan bulanan tahun 2011 - 2013 untuk mengetahui kejadian ekstrim di Riau setiap tahun.

\section{ANALISA DATA}

Analisa data yang dilakukan adalah dengan melihat ke belakang apakah data - data unsur iklim di Kota Pekanbaru mencapai kondisi ekstrim. Nilai ekstrim didapatkan dari hasil pengolahan data dengan menggunakan regresi kuantil yang mencari batasan atau threshold. Setelah didapatkan batasannya maka dianalisa secara grafik dan dibandingkan dengan kasus yang telah terjadi pada tahun 2011, 2012 dan 2013.

\section{HASIL PEMBAHASAN}

Perhitungan batas ekstrim atas dan bawah menggunakan data dari dua stasiun meteorologi di propinsi Riau, yakni dari Stasiun Meteorologi Pekanbaru dan Stasiun Meteorologi Rengat. Data yang digunakan merupakan data curah hujan dari tahun 1981 hingga 2012, dengan data hujan tahun

\begin{tabular}{|c|c|c|}
\hline Bulan & $\begin{array}{c}\text { Batas } \\
\text { Ekstrim } \\
\text { Atas }\end{array}$ & $\begin{array}{c}\text { Batas } \\
\text { Ekstrim } \\
\text { Bawah }\end{array}$ \\
\hline Januari & 421.3 & 72.5 \\
\hline Februari & 302.5 & 50.0 \\
\hline Maret & 417.9 & 125.8 \\
\hline April & 406.4 & 98.5 \\
\hline Mei & 396.4 & 95.5 \\
\hline Juni & 255.8 & 49.0 \\
\hline Juli & 310.4 & 28.0 \\
\hline Agustus & 398.8 & 53.3 \\
\hline September & 426.2 & 74.0 \\
\hline Oktober & 518.3 & 87.9 \\
\hline November & 426.3 & 142.4 \\
\hline Desember & 448.5 & 112.3 \\
\hline \multicolumn{3}{|c|}{$\begin{array}{c}\text { Tabel 1. Batas Ekstrim Stasiun Meteorologi } \\
\text { Pekanbaru }\end{array}$} \\
\hline Bulan & $\begin{array}{l}\text { Batas } \\
\text { Ekstrim Atas }\end{array}$ & $\begin{array}{l}\text { Batas } \\
\text { Ekstrim } \\
\text { Bawah }\end{array}$ \\
\hline Januari & 400.1 & 123.4 \\
\hline Februari & 240.2 & 51.2 \\
\hline Maret & 434.3 & 61.1 \\
\hline April & 374.7 & 153.6 \\
\hline Mei & 377.0 & 83.8 \\
\hline Juni & 257.4 & 59.5 \\
\hline Juli & 213.8 & 14.3 \\
\hline Agustus & 258.5 & 34.8 \\
\hline September & 272.2 & 26.6 \\
\hline Oktober & 373.2 & 66.9 \\
\hline November & 405.0 & 120.9 \\
\hline Desember & 431.4 & 117.2 \\
\hline
\end{tabular}
2013 sebagai data yang diuji terhadap kedua batas nilai ini. Hasil perhitungan nilai ekstrim untuk kedua wilayah adalah sebagai berikut.
Tabel 2. Batas Ekstrim Stasiun Meteorologi Rengat

Masing masing batas ekstrim atas dan bawah didapat dengan metode regresi kuantil. Pola curah hujan ekstrim setiap bulan, baik ekstrim atas maupun ekstrim bawah, hampir sama dengan pola curah hujan bulanan untuk wilayah Riau yang menganut pola curah hujan ekuatorial, dengan dua puncak curah hujan. Puncak curah hujan pertama di wilayah Riau biasanya terdapat pada bulan Maret hingga April, demikian pula dengan batas ekstrim atas kedua stasiun yang berada pada bulan Maret, serta batas bawah keduan stasiun yang berada pada bulan Maret untuk stasiun meteorologi Pekanbaru dan bulan April untuk stasiun meteorologi Rengat. Puncak curah hujan kedua untuk wilayah Riau terdapat pada bulan Oktober hingga November. Hal ini juga terlihat pada 'puncak batas ekstrim atas kedua 
stasiun, yakni bulan Oktober untuk stasiun meteorologi Pekanbaru dan bulan Desember untuk stasiun meteorologi Rengat. Demikian pula untuk 'puncak' batas ekstrim bawah kedua stasiun yang berada pada bulan Juli.

Kejadian curah hujan yang terjadi melebihi batas ekstrim atas atau yang kurang dari batas ekstrim bawah dikatakan sebagai kejadian ekstrim. Penggunaan batasan ekstrim ini digunakan untuk mengevaluasi kejadian hujan bulanan pada tahun 2011 hingga 2013 di masing masing stasiun. Jika dilihat dalam grafik dalam gambar 1, gambar 2, dan gambar 3, terlihat bahwa terdapat beberapa nilai yang berada di di atas batas ekstrim atas dan di bawah batas ekstrim bawah di kedua stasiun.

\section{- 2011}

Untuk stasiun meteorologi Pekanbaru, nilai ekstrim terdapat pada bulan April dan Mei 2011 dengan jumlah hujan bulanan melebihi batas ekstrim atas. Pada bulan April 2011, jumlah curah hujan bulanan di stasiun meteorologi Pekanbaru mencapai $436.1 \mathrm{~mm}$, sementara batas ekstrim atas pada bulan April hanya $406.4 \mathrm{~mm}$. Pada bulan Mei 2011, jumlah curah hujan bulanan di stasiun meteorogi Pekanbaru mencapai 540.3 $\mathrm{mm}$, lebih tinggi dari batas ekstrim atas untuk bulan Mei, yakni hanya $396.4 \mathrm{~mm}$.

Untuk stasiun meteorologi Rengat, nilai ekstrim terdapat pada bulan Mei 2011, dengan jumlah hujan bulanan kurang dari batas ekstrim bawah. Pada bulan Mei 2011, jumlah curah hujan stasiun meteorologi Rengat hanya $80.4 \mathrm{~mm}$, dimana batas ekstrim bawah untuk bulan Mei adalah 83.8 $\mathrm{mm}$.

\section{- 2012}

Untuk stasiun meteorologi Pekanbaru, nilai ekstrim terdapat pada bulan Januari 2012 dengan jumlah hujan bulanan kurang dari batas ekstrim bawah, serta pada bulan November 2012, dengan jumlah hujan bulanan melebihi batas ekstrim atas. Pada bulan Januari 2012, jumlah curah hujan bulanan di stasiun meteorologi Pekanbaru hanya $66.4 \mathrm{~mm}$, sementara batas ekstrim bawah untuk wilayah Pekanbaru pada bulan Januari adalah $72.5 \mathrm{~mm}$. Sebaliknya, pada bulan November 2012, curah hujan bulanan di stasiun meteorologi Pekanbaru mencapai 440.5 $\mathrm{mm}$, sementara batas ekstrim atas pada bulan November hanya $426.3 \mathrm{~mm}$.

Untuk stasiun meteorologi Rengat, nilai ekstrim terdapat pada bulan Februari, dan November 2012, dengan jumlah hujan bulanan melebihi batas ekstrim atas serta pada bulan Januari dan Juni 2012, dengan jumlah hujan bulanan kurang dari batas ekstrim bawah. Pada bulan Februari 2012, jumlah curah hujan bulanan di stasiun meteorologi Rengat mencapai $327.6 \mathrm{~mm}$, sementara batas ekstrim atas pada bulan Februari hanya 240.2 mm. Pada bulan November
2012, jumlah curah hujan bulanan di stasiun meteorologi Pekanbaru mencapai $561.0 \mathrm{~mm}$, sementara batas ekstrim atas pada bulan November hanya $405.0 \mathrm{~mm}$. Sebaliknya, pada bulan Januari 2012, jumlah curah hujan stasiun meteorologi Rengat hanya $27.4 \mathrm{~mm}$, jauh lebih rendah dari batas ekstrim bawah untuk bulan Januari yakni $123.4 \mathrm{~mm}$. Demikian pula pada bulan Juni 2012, jumlah curah hujan stasiun meteorologi Rengat hanya $31.5 \mathrm{~mm}$, dimana batas ekstrim bawah untuk bulan Juni adalah $59.5 \mathrm{~mm}$.

\section{$-2013$}

Untuk stasiun meteorologi pekanbaru, nilai ekstrim terdapat pada bulan Februari dan Desember dengan jumlah hujan bulanan melebihi batas ekstrim atas. Pada bulan Februari 2013, jumlah curah hujan bulanan di stasiun meteorologi Pekanbaru mencapai $338.4 \mathrm{~mm}$, sementara batas ekstrim atas pada bulan Februari hanya 301.0 mm. Pada bulan Desember 2013, jumlah curah hujan bulanan di stasiun meteorogi Pekanbaru mencapai $615.1 \mathrm{~mm}$, jauh lebih tinggi dari batas ekstrim atas untuk bulan Desember, yakni hanya $448.2 \mathrm{~mm}$.

Untuk stasiun meteorologi Rengat, nilai ekstrim terdapat pada bulan Februari, April, dan Oktober, dengan jumlah hujan bulanan melebihi batas ekstrim atas serta pada bulan Juni dengan jumlah hujan bulanan kurang dari batas ekstrim bawah. Pada bulan Februari 2013, jumlah curah hujan bulanan di stasiun meteorologi Rengat mencapai $371.2 \mathrm{~mm}$, sementara batas ekstrim atas pada bulan Februari hanya $280.5 \mathrm{~mm}$. Pada bulan April 2013, jumlah curah hujan bulanan di stasiun meteorologi Rengat mencapai $417.8 \mathrm{~mm}$, sementara batas ekstrim atas pada bulan April hanya $373.3 \mathrm{~mm}$. Pada bulan Oktober 2013, jumlah curah hujan bulanan di stasiun meteorologi Pekanbaru mencapai $409.7 \mathrm{~mm}$, sementara batas ekstrim atas pada bulan Oktober hanya $374.3 \mathrm{~mm}$. Sebaliknya, pada bulan Juni 2013, jumlah curah hujan stasiun meteorologi Rengat hanya $38.2 \mathrm{~mm}$, dimana batas ekstrim bawah untuk bulan Juni 2013 adalah $52.0 \mathrm{~mm}$.

Pada tahun 2011, curah hujan ekstrim terjadi pada bulan Mei 2011 di kedua stasiun, namun kecenderungan yang terjadi berlawanan. Di stasiun meteorologi Pekanbaru, ekstrim yang terjadi adalah ekstrim yang melebihi batas atas, sementara di stasiun meteorologi Rengat, ekstrim yang terjadi adalah ekstrim yang berada di bawah batas ekstrim bawah. Kemungkinan peristiwa ekstrim yang terjadi bersifat sangat lokal dan tidak dapat dikategorikan untuk seluruh Riau.

Pada tahun 2012, data dari kedua stasiun sama sama menunjukkan nilai ekstrim di atas batas ekstrim atas pada bulan November 2012, dan nilai ekstrim di bawah batas ekstrim bawah pada Januari 2012. Pada tahun 2013, data dari kedua 
stasiun sama sama mengalami curah hujan ekstrim yang melebihi batas ekstrim atas pada bulan Februari. Menjelang akhir tahun, mulai dari Oktober hingga Desember, curah hujan bulanan umumnya cukup tinggi, bahkan hingga melewati batas ekstrim atas pada bulan Oktober untuk Stasiun Meteorologi Rengat dan bahkan jauh melewati batas ekstrim atas Stasiun Meteorologi Pekanbaru pada bulan Desember.

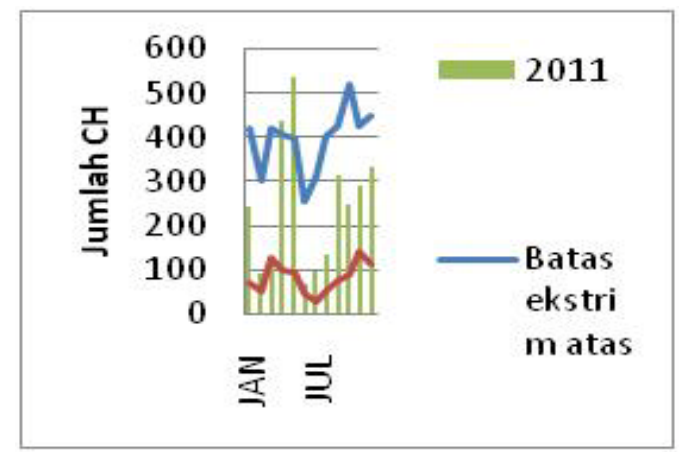

(a)

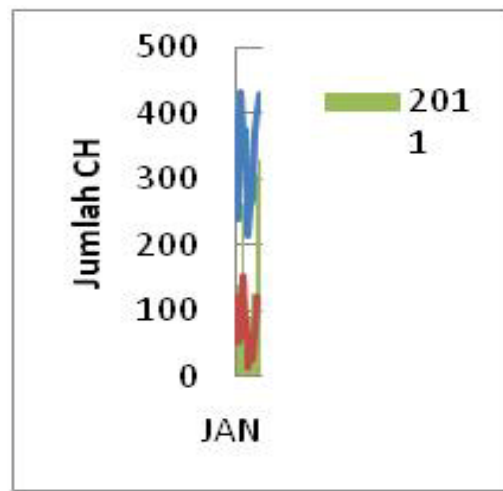

(b)

Gambar 1. Perbandingan curah hujan bulanan tahun 2011 dengan batas ekstrim di stasiun meteorologi (a) Pekanbaru, (b) Rengat.

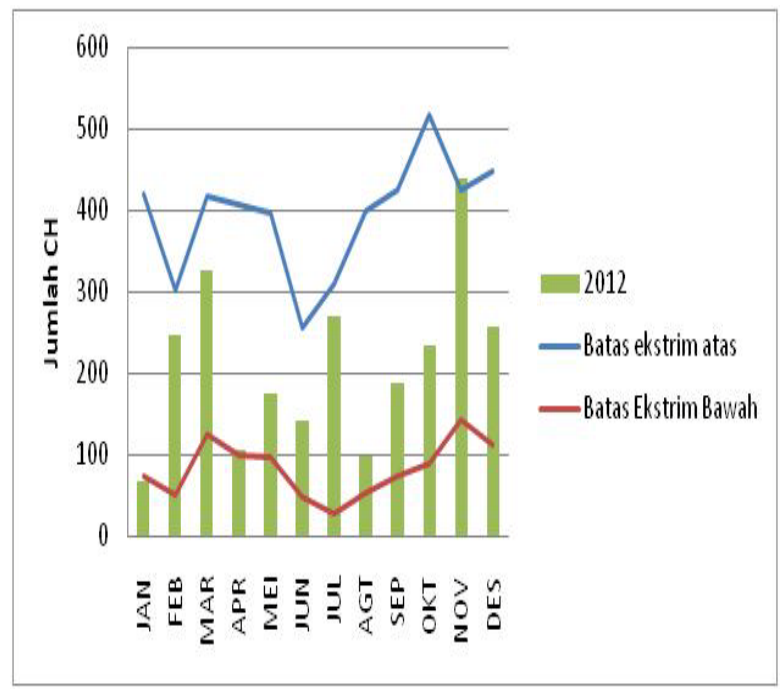

(a)

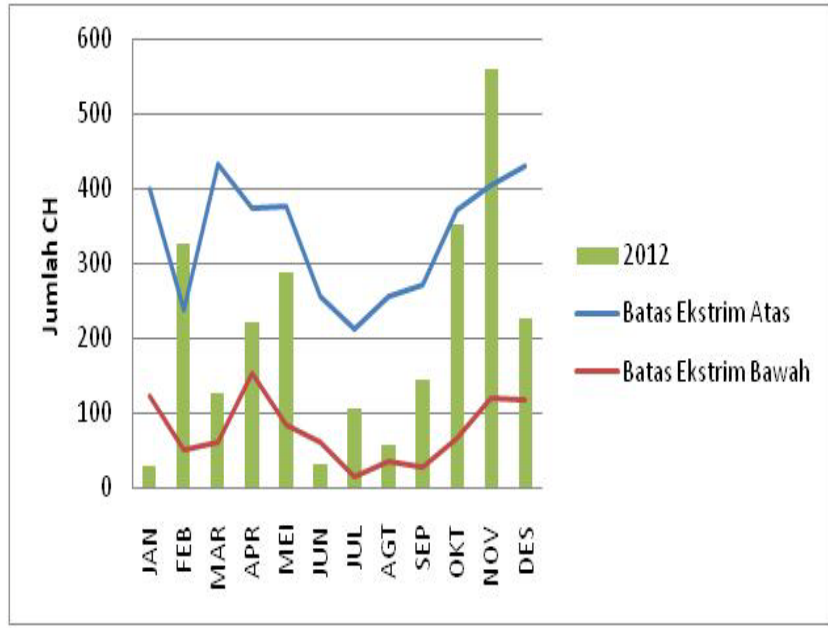

(b)

Gambar 2. Perbandingan curah hujan bulanan tahun 2012 dengan batas ekstrim di stasiun meteorologi (a) Pekanbaru, (b) Rengat.



(a)

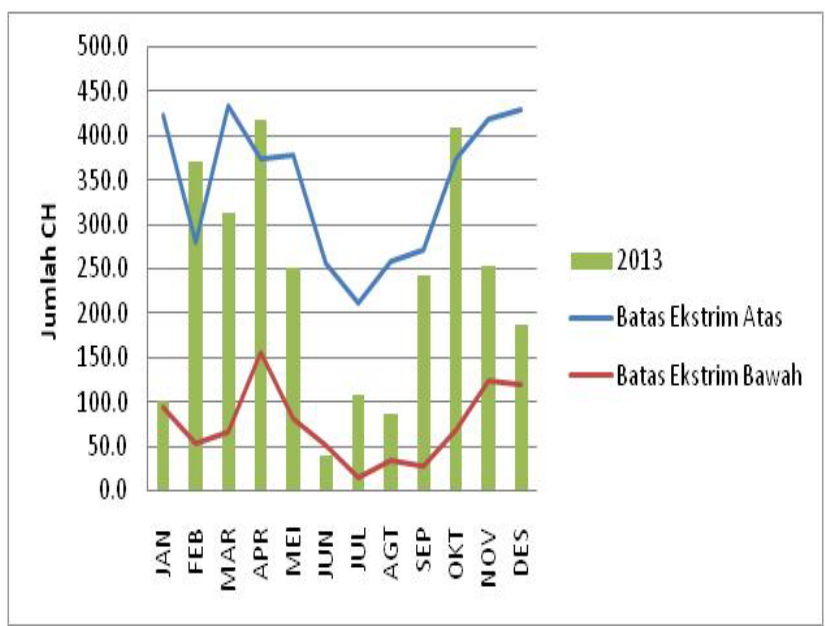

(b)

Gambar 3. Perbandingan curah hujan bulanan tahun 2013 dengan batas ekstrim di stasiun meteorologi (a) Pekanbaru, (b) Rengat. 


\section{KESIMPULAN}

Dari Perhitungan batas ekstrim atas dan bawah menggunakan data dari dua stasiun meteorologi di propinsi Riau, yakni dari Stasiun Meteorologi Pekanbaru dan Stasiun Meteorologi Rengat dapat disimpulkan kedua wilayah adalah sebagai berikut.

1. Masing masing batas ekstrim atas dan bawah didapat dengan metode regresi kuantil di kedua tempat dengan pola curah hujan bulanan ekuatorial hampir sama.

2. Batas ekstrim atas kedua stasiun, yakni bulan Oktober untuk stasiun meteorologi Pekanbaru dan bulan Desember untuk stasiun meteorologi Rengat.

3. Batas ekstrim bawah kedua stasiun yang berada pada bulan Juli, untuk Pekanbaru batas bawahnya dengan curah hujan 28 $\mathrm{mm} /$ bulan sedangkan untuk Stamet Japura Rengat nilai batas bawahnya $14.3 \mathrm{~mm} / \mathrm{bulan}$

\section{DAFTAR PUSTAKA}

Barnett, V. And Lewis T. 1994. Outliers in Statistibcal Data. John Wiley. New York.

Boer, Rizaldi dan Perdinan. 2008. Adaptation to climate variability and climate change: Its socio-economic aspect. Paper presented at the EEPSEA Conference On Climate Change: Impacts, Adaptation, And Policy In South East Asia With A Focus On Economics, Socio-Economics And Institutional Aspects, 13-15 February 2008, Bali, <http://www.eepsea.ccsea.org>, diakses tanggal 11 Februari 2012.

Gibbs, J. W. 1987. Definiting Climate. WMO Buletin No. 4, Vol. 36, Oct 1987.

IPCC (Intergovernmental Panel on Climate Change). 2007. Climate change 2007. Synthesis report.Contribution of Working Groups I, II and III to the Fourth Assessment Report of the Intergovernmental Panel on Climate Change.

Kasry, A .Ekologi Lingkungan, Bahan ajar pada program Ilmu Lingkungan UNRI, 2013

Koenker, R. and Basset, G. 1978. Regression Quantile, Econometrica. January, 46:1, pp. 33-50.

Koenker, R. and Hallock, K.F. 2001. Quantile Regression, The Journal of EkonomicPerspectives, Vol. 15, No. 4, pp. 143-156 Published by: American Economic Association.

Muchtar, E., H.R. Sunoko, W. Sulistya. 2012. Kajian Kerentanan Masyarakat terhadap Perubahan Iklim Berbasis Daerah Aliran Sungai (Studi Kasus Sub DAS Garang Hulu). Jurnal IImu Lingkungan. Vol. 10(1).pp: 8-18.

Mudiyarso, D. 2003. Protokol Kyoto, Implikasinya Bagi Dunia Berkembang, Buku.
Koenker, R. 2005. Quantile Regression. Cambridge: Cambridge University Press. Roger, R., (1980). Cloud Physics. Pergamon Press. New York.

Susandi, A., I. Herlianti, M. Tamamadin, I. Nurlela. 2008. Dampak Perubahan Iklim terhadap Ketinggian Muka Laut di Wilayah Banjarmasin. Jurnal Ekonomi Lingkungan. Volume 12, No 2.

Thewartha , R. 1980. Global Climate. Journal ( page : 3 ). New York.

Wigena, A. H. 2012. Penentuan Nilai Ekstrim dengan Regresi Kuantil. Modul Penyusunan Standar Informasi Iklim Ekstrim. Tidak dipublikasikan. BMKG. Jakarta Change. 